\title{
Four Decades, Four Places and Four Concepts
}

\author{
Manfred Mutter*
}

\begin{abstract}
Peptide chemistry has experienced enormous progress over the last decades, and the synthesis-oriented peptide scientist is confronted today with research domains at the interface of chemistry, biology and medicine. In this review, we look at some of our contributions over four decades, developed at four places in Germany and Switzerland. Special attention is given to four concepts which can be considered as nucleation seeds for some of today's research topics in peptide chemistry: (1) The use of polyethylene glycols (PEG) as solubilizing carriers in liquid-phase peptide synthesis which has resulted in the well known 'PEGylation' of peptides and proteins, (2) the construction of artificial proteins using topological templates, termed template-assembled synthetic proteins (TASP) which has stimulated the use of templates in peptide and protein design and mimicry, (3) pseudo-prolines which serve today as routine technology for the prevention of peptide self-association and beta-sheet formation in peptide synthesis, thus making accessible solid-phase synthesis of peptides up to the size of small proteins, and finally (4) studies on the onset of secondary structure and conformational transitions in designed oligopeptides which resulted in the creation of 'switch-peptides' as folding precursors, allowing delineation of the molecular mechanism of protein folding and misfolding as an early step in peptide self-assembly and fibril formation relevant in degenerative diseases.
\end{abstract}

Keywords: PEGylation · Pseudo-prolines · Switch-peptides · Template-assembled synthetic proteins (TASP)

\section{Introduction}

At the interface between small molecules and proteins, peptides exhibit some unique functional and biological properties, making them an interesting target for academic and industrial research. Due to enormous progress in the synthesis of peptides, research efforts have shifted from synthetic chemistry in earlier times to biological chemistry. As a consequence, today's peptide chemistry is an interdisciplinary domain, unifying nearly all disciplines of natural sciences. Once synthetic peptides became easily accessible via solid-phase peptide synthesis (SPPS), studies over the last four decades focused on structure-activity relationship, bioactive conformation, and secondary and tertiary structure formation. Because of intrinsic limitations in the use of peptides as orally active drugs, industrial interest in this class of biomolecules has experienced many ups and downs over the years, which is perfectly illustrated by the appearance and disappearance of well-established and sci-

${ }^{\star}$ Correspondence: Prof. Dr. M. Mutter

Debiopharm Research \& Manufacturing S.A.

Campus 'après-demain'

Rue du Levant 146, CP 368

$\mathrm{CH}-1929$ Martigny

Tel.: +41277217900

E-mail: manfred.mutter@debiopharm.com

The author would like to dedicate this review to Dr.

Rolland-Yves Mauvernay, President and Founder of

Debiopharm Group, Lausanne. entifically eminent peptide groups in major pharmaceutical companies. A particular focus has been the development of nonpeptidic molecules ('peptido-mimetics') derived from bioactive conformations of peptides by rational design. However, despite the immense progress of theoretical, biochemical and analytical (notably spectroscopic) tools, the transformation of native peptides into orally active drugs has turned out to be an exceptionally challenging task.

Today, we observe a renaissance of therapeutic peptides, driven mostly by progress in the technology of large-scale production using SPPS, by peptide delivery and by unmet medical needs. In view of their central function in the control of protein-protein interactions, peptides as a link between small molecules and macromolecules will continue to be in the focus of academic and industrial research for the development of therapeutically interesting compounds in the near future.

In the present article, some of our contributions to this stimulating research field are discussed, with focus on their 'sustainable impact' for present and future developments. Because the author was in the privileged situation of receiving inspirations from different places in Germany and Switzerland over his academic career, the evolution of four concepts, i.e. (1) polyethylene glycols (PEG) for peptide synthesis and conformational studies, (2) templateassembled synthetic proteins (TASP) in protein de novo design, (3) pseudo-prolines
( $\Psi$-Pro) as structure-disrupting building blocks and (4) switch-peptides as folding precursors, are retraced to the sites of their discovery, the Universities of Tübingen, Mainz, Basel and Lausanne/EPFL.

\section{Polyethylene Glycols (PEG) for Peptide Synthesis and Conformational Studies}

Peptide synthesis was revolutionized by the ingenious idea of Bruce Merrifield to simplify the reaction cycle by fixing the growing peptide chain to an insoluble carrier. ${ }^{[1]}$ When the author entered the field in the early 1970s, solid-phase peptide synthesis (SPPS) was the center of contentious discussions due to some intrinsic problems in heterogeneous synthesis, which resulted in impure crude material due to incomplete reactions as the origin of 'failure' and truncated sequences ${ }^{[2]}$ and was far from being accepted for the synthesis of peptides for therapeutic use. As a naïve $\mathrm{PhD}$ student, the use of soluble supports, i.e. working in a liquid (homogeneous) phase seemed the ideal solution to overcome these problems. And having 'discovered' PEG in the lab, we fixed the growing peptide chain to the chain ends of PEG 5'000-20'000. [3] The unique properties of PEG, most notably its high solubility in both organic and aqueous media and its tendency to crystallize from ether and alcoholic systems - unshared by any other functional polymer - resulted in a convenient and efficient method for pep- 
tide synthesis and isolation. ${ }^{[4]}$ When we presented the liquid-phase method (LPM) at the $7^{\text {th }}$ American Peptide Symposium, Claudio Toniolo (University of Padua) proposed a collaboration on the use of PEGbound peptides in conformational studies which resulted in a fruitful partnership over many years. By making use of the strong solubilizing power of PEG (Fig. 1), the onset of secondary structure formation of hydrophobic peptides could be studied in water and organic media. ${ }^{[5]}$ One of the key observations in the study of PEG-boundpeptides (today 'PEGylated peptides') was the dramatic change of physico-chemical properties during coupling reactions.

We could demonstrate that conformational transitions of the type random-coil (rc) to $\beta$-sheet were at the origin of some fundamental problems in conventional solution strategies (insoluble sequences) as well as in SPPS (incomplete reactions as source of truncated and failure sequenc$\mathrm{es}^{[2]}$ ).

Consequently, the impact of secondary structure formation on reaction kinetics has become an important element in planning peptide synthesis. ${ }^{[6]}$ When Bruce Merrifield took notice of this aspect (later termed 'difficult sequences'), he commented to the author: "Excellent, someone has to take care of this problem". In addition, the identification of conformational changes as the origin of incomplete reaction steps in polystyrene-based SPPS triggered the design of more hydrophilic carriers exhibiting higher solvation power such as cross-linked PEG-polystyrene (today 'Tentagel', Rapp Polymere, Tübingen) or polyamine- ('Sheppard') resins. ${ }^{[7]}$

Based on the precedent of using PEG as a solubilizing group in peptide synthesis and in conformational studies, ${ }^{[8]}$ the potential of PEG to modify physico-chemical and biological properties of peptides and proteins was recognized and has found use in multiple research areas including pharmacological applications. ${ }^{[9]}$ Notably, the early findings ${ }^{[10]}$ that PEGylation altered the immunological and pharmacological properties of proteins enlarged the spectrum of PEGylation to clinical applications. Ironically, when we first proposed the terms 'PEGylation' and 'PEGylated' for PEG-bound peptides and derivatives, the referee refused to accept these terms, an incomprehensible decision from today's point of view.

\section{Template-assembled Synthetic Proteins (TASP) in Protein de novo Design}

One of the most challenging topics in peptide and protein chemistry is the problem of how a polypeptide chain folds into its bioactive three-dimensional structure. This 'protein folding problem' has been regarded as the key to predicting structure and function of a given peptide sequence and the prediction of 3D-structures based on theoretical energy calculations remains difficult. ${ }^{[11]}$ Similarly, the construction of artificial proteins with tailored structural and functional features represents a most ambitious goal in protein de novo design. ${ }^{[12]}$
With the foundations of secondary structure formation of oligo-peptides in place, the use of topological templates for the induction of 3D-structures appeared a most attractive way to bypass the protein folding problem. In the strategy of TASP, secondary-structure-forming oligo-peptides are assembled on a topological template which directs these blocks to a predetermined 3D-structure ${ }^{[13]}$ (Fig. 2).

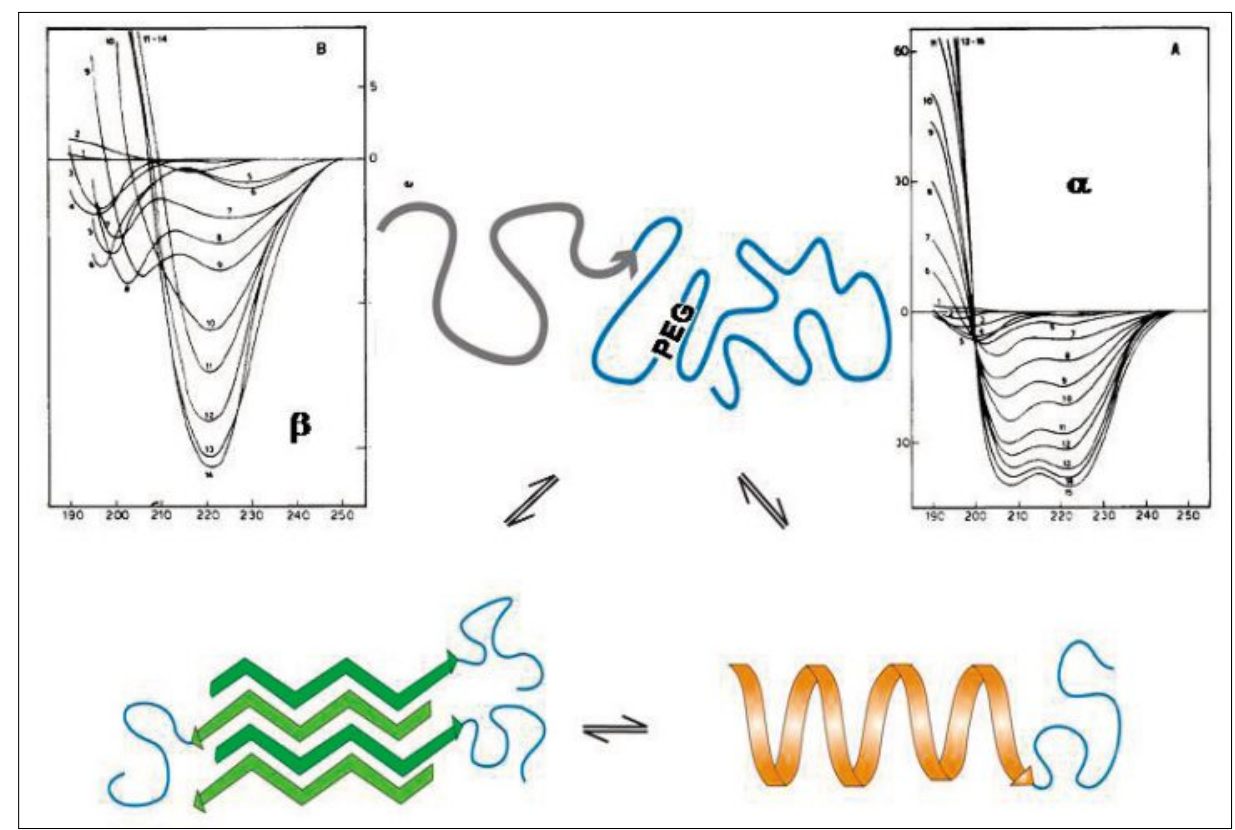

Fig. 1. PEG for peptide synthesis and conformational studies. CD spectra of PEG-bound ('PEGylated') peptides for the study of the critical chain length for secondary structure formation ( $\beta$-sheet in $\mathrm{H}_{2} \mathrm{O}$, left; $\alpha$-helix in TFE, right) of homo-oligopeptides. ${ }^{[5]}$

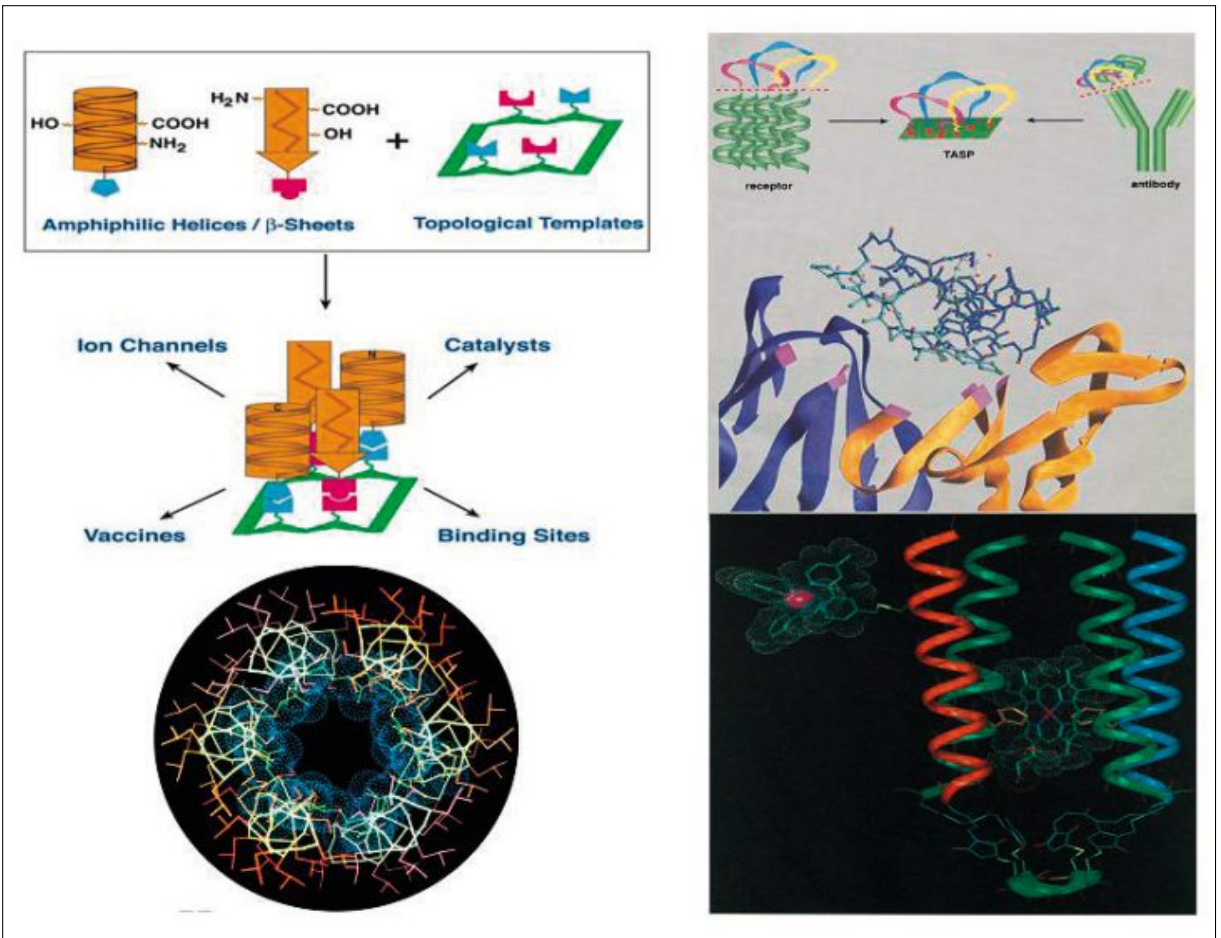

Fig. 2. The concept of template-assembled synthetic proteins, TASP: ${ }^{[13]} \alpha$-helical and/or $\beta$-sheet oligo-peptides are covalently attached to a topological template which directs the peptide blocks to a predetermined 3D-structure, e.g. artificial redox proteins (lower right ${ }^{[14]}$ ) or membrane channel forming $6 \alpha$-helix-bundles (lower left ${ }^{(15)}$ ). The covalent attachment of protein (receptor, antibody) loops results in TASP molecules as protein mimetics (upper right). ${ }^{[16]}$ 
Due to the invention of chemoselective ligation techniques in the 1990s, the creation of TASP molecules exhibiting a variety of structural and functional properties (Fig. 2) has become the focus of an increasing number of research groups. ${ }^{[13-16]}$

Today, the concept of using topological templates in the design of peptide and protein mimetics has found some promising applications. ${ }^{[17]}$ The idea of mimicking binding sites in peptides and proteins by attaching peptide blocks, ligand binding loops or small molecules onto regioselectively-addressable templates as small-sized mimetics attracted our attention early in the development of the TASP concept. ${ }^{[16]}$ In particular, we were able to create TASP molecules as prototypes of protein (enzymes, receptors, antibodies) mimetics (Fig. 2, top right). Interestingly, our early efforts to create 'protein mimetics' by applying chemical and combinatorial principles for library screening ${ }^{[16]}$ recently found a most ingenious methodological extension by the combination of phage display and chemical ligation techniques for the functional screening of templateassembled binding loops, termed 'bicyclic peptides'. ${ }^{[18]}$ Notably, the therapeutic potential of this elegant strategy (described by $\mathrm{C}$. Heinis et al. in this issue) has been exemplified by the identification of lead compounds as antibody mimetics. ${ }^{[19]}$

The often-envisioned combination of chemical and biological tools in the search for therapeutic compounds - perfectly exemplified in this approach ${ }^{[18]}$ - possibly represents one of the most promising future avenues for peptide-based drug design and protein mimicry applying the template concept.

\section{Pseudo-prolines ( $\Psi$-Pro) as Structure-disrupting Building Block}

A problem of long standing in peptide chemistry is the low solubility of many target peptides, e.g. membrane-active or sidechain protected peptides. Due to their hydrophobic nature, their synthetic access is often hampered by the onset of conformational transitions of the type rc to $\beta$-sheet structure during chain elongation. Studies on oligo-peptides have revealed the exceptional impact of a proline residue upon the preferred conformation of a peptide. As predicted from conformational energy calculations, ${ }^{[20]}$ the insertion of this amino acid into a potentially $\beta$-sheet-forming oligo-peptide results in a disruption of the secondary structure, paralleled by a significant increase in solubility. [21]

During the synthesis of $\mathrm{C}(\alpha)$ methylated serine, the structural similarity between the intermediate oxazolidines and proline inspired us ${ }^{[22]}$ to transfer the unique structural features of proline to serine-, threonine- and cysteine-derived ring structures, termed pseudo-prolines

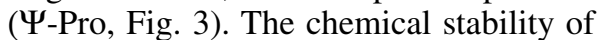
$\mathrm{C}(2)$-dimethylated derivatives corresponded perfectly to the standard methodology of side-chain protection in solid-phase peptide synthesis, which was essential for its routine use.

In addition, the presence of $\mathrm{C}(2)$ substituents strongly enhances the wellknown structure-disrupting effects of proline by the induction of a complete 'kink-structure' (presence of $100 \%$ cisamide $^{[23]}$ Fig. 4). Importantly, the use of
$\Psi$-Pro building blocks allowed the chemical synthesis of otherwise inaccessible linear and cyclic peptides or considerably improved the overall yield of long peptides by multiple insertions of $\Psi$-Pro blocks. ${ }^{[24]}$ Besides their routine use as a secondarystructure-disrupting, solubilizing protection technique in peptide synthesis, $\Psi$-Pro have been used for the elucidation and stabilization of bioactive conformations in therapeutically important peptides. ${ }^{[24-26]}$

Once we recognized the unique conformational effects of proline residues, their potential for peptide synthesis was so obvious that we immediately published our dis-

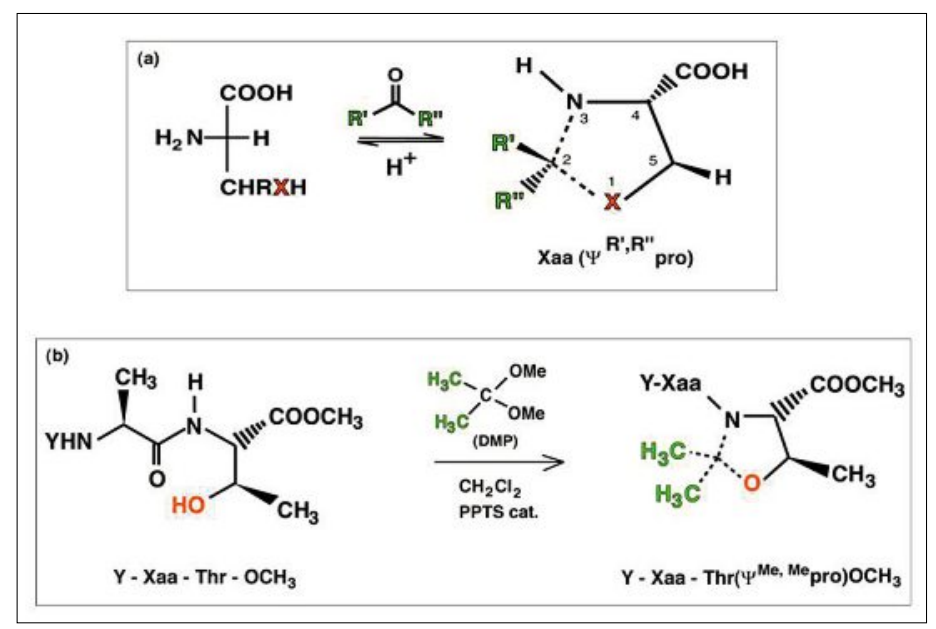

Fig. 3. The pseudo-proline concept: (a) Serine $(R=H, X=O)$, threonine $\left(\mathrm{R}=\mathrm{CH}_{3}, \mathrm{X}=\mathrm{O}\right)$ and cysteine $(\mathrm{R}=\mathrm{H}, \mathrm{X}=\mathrm{S})$ are transformed to $\mathrm{C}(2)$ substituted oxazolidins $(X=O)$ or thiazolidines $(X=S)$, termed pseudoprolines ( $\Psi$-Pro) due to their structural similarity with proline; ${ }^{[22]}$ (b) $\Psi$-Pro containing dipeptides for use in peptide synthesis are readily prepared by insertion of acetals into the $\mathrm{N}(\mathrm{Y})$-protected dipeptide esters and are commercially available today.

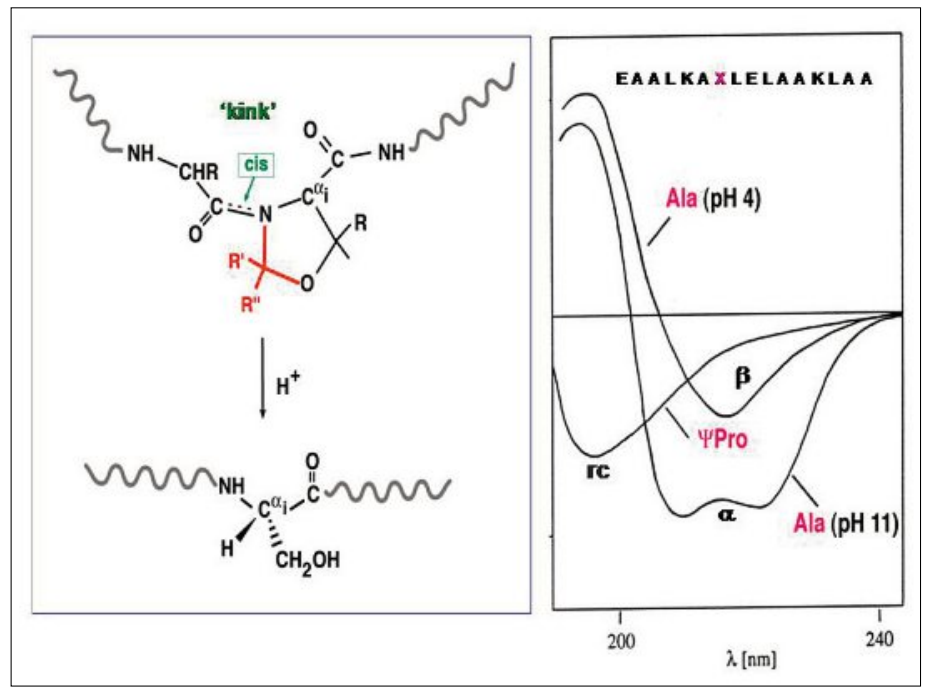

Fig. 4. The insertion of a pseudo-proline ( $\Psi$-Pro) induces a cis-amide bond ('kink') into the peptide backbone. Under acidic conditions, the oxazolidine ring is cleaved to an unprotected serine residue and the peptide adopts its regular structure (left). By insertion of a single $\Psi$-Pro $(\mathrm{X}$, right) into a potentially $\alpha$-helix (at $\mathrm{pH} 11)$ or $\beta$-sheet $(\mathrm{pH} 4)$ forming oligo-peptide, the secondary structures are completely disrupted and the 16-mer peptide adopts a flexible random-coil ( $\mathrm{rc}$ ) in $\mathrm{H}_{2} \mathrm{O}$ as depicted by CD. ${ }^{[23]}$ 
covery. ${ }^{[22]}$ Ironically, only about 10 years later, one could observe a more general acceptance for the routine use of the $\Psi$-Pro concept in peptide synthesis, triggered primarily by the commercial availability and competitive price of the corresponding building blocks. Given the novelty of the concept and today's market of $\Psi$-Pro building blocks, we obviously missed the opportunity to file a commercially significant patent, clearly a tribute to our purely academic thinking!

\section{Switch-peptides as Folding Precursors}

The study of conformational transitions was long considered as an academic exercise without any relevance for biological processes. This attitude completely changed when the folding and misfolding of peptides and proteins moved into the center of interest because of their impact on neurodegenerative diseases.[26-28] For example, transitions of soluble amyloid $\beta$ precursor molecules into aggregated, $\beta$-sheet forms play a key role in the deposition of cerebral amyloid plaques characteristic of Alzheimer's disease. Similarly, $\alpha$-helix to $\beta$-sheet transitions are considered as the molecular origin of the transformation of the physiological form of prion protein into the pathological form.

In the first generation of 'switch-peptides' we could demonstrate that minor changes in concentration, solvent or temperature could induce spontaneous conformational transitions. [29]

For the study of early processes in folding, the establishment of the sequence and the onset of the folding process must proceed in two distinct steps and corresponds to the fundamental concept of the second generation of switch-peptides, where the target molecule is prepared as a flexible, unfolded precursor molecule (Soff-state in Fig. 5).

According to this concept, ${ }^{[30]}$ 'switch elements' derived from serine or threonine and prone to $\mathrm{O}-\mathrm{N}$-acyl migration are inserted into a peptide backbone. Due to the modified structural features, the peptide adopts a flexible random-coil structure (Soff). By triggering O-N-acyl migration, the regular backbone is restored (Son) and the folding process can be studied 'in statu nascendi' of the molecule. While we made use of the $\mathrm{O}-\mathrm{N}$-acyl migration for triggering conformational transitions of peptides, other groups simultaneously applied this well-known reaction ${ }^{[31]}$ as a tool for overcoming the solubility problem of hydrophobic peptides. ${ }^{[32,33]}$

In applying the concept to longer peptides or proteins, the insertion of several switch elements combined with orthogo-

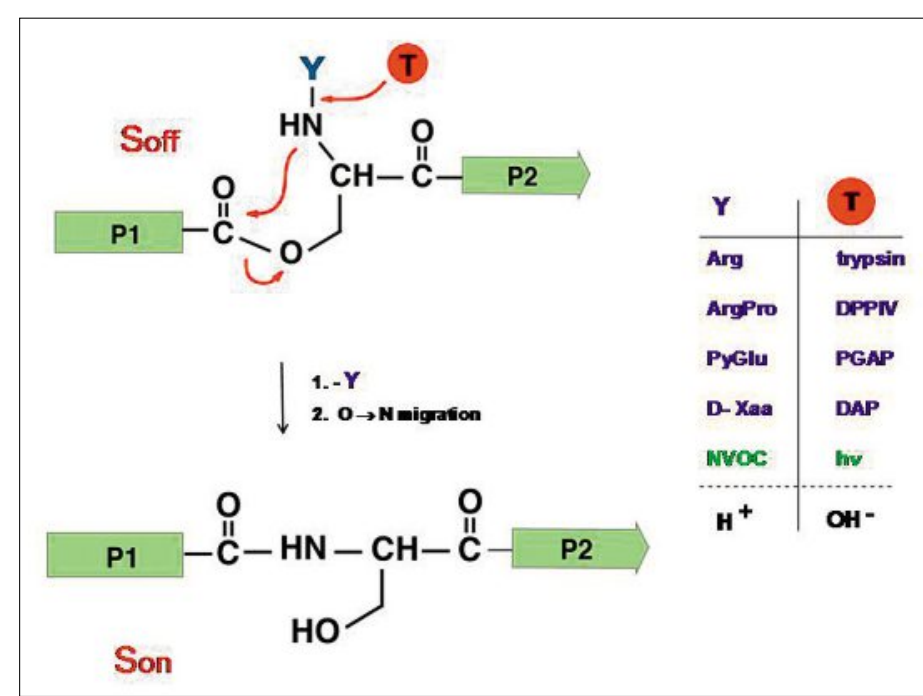

Fig. 5. Concept of switch-peptides: ${ }^{[30]}$ In triggering $\mathrm{O}-\mathrm{N}$ acyl migration, the ester bond containing peptide (Soff) transforms into the regular peptide backbone (Son), paralleled by a drastic change in its physico-chemical and biological properties. A variety of chemical enzymatic or photolytic methods $(T)$ can be used to remove the $\mathrm{N}$-protection group $(Y)$

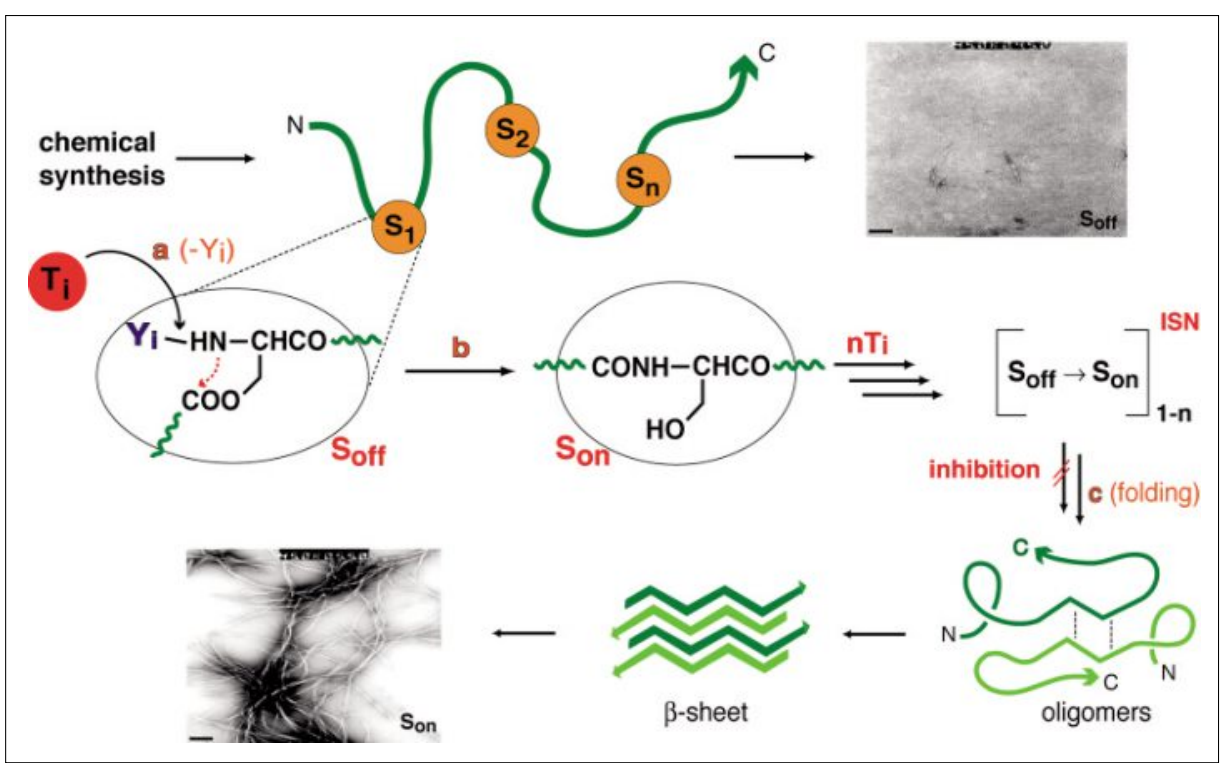

Fig. 6. Switch-peptides as folding precursors: Consecutive triggering of O-N-acyl migrations in amyloid $\beta$-derived switch-peptides (Soff) for the onset of peptide folding, self-association and fibril formation (Son) ${ }^{[30,34]}$

nal N-protecting groups (Y) allows for the selective triggering (Son) of segments, revealing detailed information about the molecular mechanism of chain assembly and folding (Fig. 6). ${ }^{[34]}$

According to current hypotheses, most proteins adopt an energetically metastable state under physiological conditions, and minor changes in situ may induce irreversible conformational transitions, e.g. from helical to $\beta$-sheet ('conformational energy sink'). Based on the understanding of these mechanisms in proteins of therapeutic interest, the development of molecules with a propensity to stabilize native globular conformations and thus to inhibit conformational transitions as the molecular origin of degenerative diseases may not be unrealistic in the near future (Fig. 6).

\section{Conclusions}

The concepts described in this review may be considered as modest 'building blocks' for today's state of the art in peptide science. Some serve as nucleation seeds (the 'PEGylation' and the 'template' story), others as a bridge to proteins (the 'switch-peptides') or as contribution to peptide synthesis (the 'pseudo-prolines').

Today's profile of a 'peptide chemist' - best reflected in the programs of the ever-increasing number of international meetings in the field - shows that he must be multifunctional, interactive and flexible - in full harmony with the properties of his dedicated subject, the PEPTIDES, and most luckily, this new generation of peptide chemists is present in Switzerland, as this special issue demonstrates.

Besides the usual 'ups and downs' in the evolution of peptide chemistry - with as many renaissances as dark ages - the 
characteristic features of a 'peptide chemist' have completely changed, largely due to progress in his own field. For example, after the discovery of solid-phase synthesis the chemical synthesis of peptides was no longer considered an art.

A most significant change occurred when ever more powerful computers entered their laboratories, accompanied by considerable hype. New theoretical tools seemed to replace chemist's intuition, and 'rational drug design' was considered as 'the king's pathway' for transforming peptides to orally active drugs. After hard lessons in the school of experimental reality, peptide chemists have learned that peptides have a 'difficult character' - hard to predict in their behavior in vivo, hard to mimic with small molecules and hard to characterize by general rules. Curiously, the cyclic peptide cyclosporine is orally active, in contrast to all empirical predictions. Attempts to use some of its specific structural characteristics as a general feature for the design of orally active peptide therapeutics represent at least a promising first step. ${ }^{[35]}$

Over the last years, peptide chemists initiated alternative routes for overcoming the well-known intrinsic limitations of 'peptides as drugs' by directing their efforts to novel delivery forms. In particular, conjugates, liposomes, polymeric micelles, dendrimers and nano-particles have received much attention, and targeted drug delivery to the site of biological action appears an exceptionally challenging goal for the therapeutic use of peptides. ${ }^{[36]}$

The younger reader of this short review might be hesitant to receive lessons from 'The Golden Age of Peptide Chemistry', [37] so let me thank my students, colleagues and friends for the most valuable lessons I learned during the last four decades. When I complained as a young professor about some 'difficult characters', an older friend gave me the advice: "Be sure to always have about twenty percent of this type around". Ever since, I have followed this '20 percent rule' courageously, and since a recent article entitled 'Crazy Types - How disturbed must one be to perform exceptionally?', ${ }^{[38]}$ I know that this rule has a high impact factor.

\section{Acknowledgements}

The author is deeply indebted to his students and co-workers during his entire academic career. We are grateful for much national and international collaboration with academic and industrial research groups. The research described was mainly supported by the Deutsche Forschungsgemeinschaft (DFG), Swiss National Science Foundation (SNSF), by grants from the Universities of Tübingen, Mainz, Basel, Berlin, Lausanne and the Ecole Polytechnique Fédérale de Lausanne (EPFL) as well as by industrial grants from BASF,
Hoffmann-La Roche, Ciba-Geigy, Sandoz, Novartis and Debiopharm Group. Finally the author is grateful to his academic advisors Max Brenner, Ernst Bayer and Paul J. Flory for triggering his enthusiasm for peptides, and to Debiopharm Research and Manufacturing, Martigny, for offering the chance to continue his life-long studies in Peptide Science in a stimulating industrial environment after his retirement from academia.

Received: September 11, 2013

[1] R. B. Merrifield, J. Amer. Chem. Soc. 1963, 85, 2149.

[2] E. Bayer, H. Eckstein, K. Hägele, W. A. König, W. Brüning, H. Hagenmaier, W. Parr, J. Am. Chem. Soc. 1970, 92, 1735.

[3] M. Mutter, H. Hagenmaier, E. Bayer, Angew. Chem. Int. Ed. Engl. 1971, 10, 811.

[4] M. Mutter, E. Bayer, Angew. Chem. Int. Ed. 1974, 13,88

[5] C. Toniolo, G. M. Bonora, M. Mutter, J. Am. Chem. Soc. 1979, 101, 450; G. M. Bonora, C. Toniolo, M. Mutter, Polymer 1978, 19, 1382; C. Toniolo, G.M. Bonora, S. Salardi, M. Mutter, Macromol. 1979, 12, 620.

[6] M. Mutter, V. N. R. Pillai, H. Anzinger, E. Bayer, C. Toniolo, in 'Peptides', Proc. Eur. Pept. Symp. 16th, Ed. K. Brunfeldt, 1981, p. 660.

[7] H. Becker, H.-W. Lucas, J. Maul, V. N. R. Pillai, H. Anzinger, M. Mutter, Makromol. Chem. Rapid Commun. 1982, 3, 217; A. R. Vaino, K. D. Janda, J. Combinat. Chem. 2000, 2, 579.

[8] V. R. Pillai, M. Mutter, Acc. Chem. Res. 1981, 14, 122.

[9] S. M. Ryan, G. Mantovani, X. Xuaxuan, D. M. Haddleton, D. J. Brayden, Exp. Opin. Drug Deliv. 2008, 5, 371; V. B. Damodaran, C. J. Fee, Eur. Pharm. Rev. 2010, 15, 18; C.J. Fee, V.B. Damodaran, in 'Biopharmaceutical Production Technology', Ed. G. Subramanian, WileyVCH Verlag GmbH \& Co. KGaA, Weinheim, Germany, 2012; A. Zier, D. Ryan, M. Mutter, Tetrahedron Lett. 1994, 35, 1039.

[10] A. Abuchowski, T. Van Es, N. C. Palczuk, F. F. Davis, J. Biol. Chem. 1977, 252, 3578; K. Geckeler, M. Mutter, Z. Naturforschung 1979, 34b, 1024; F. F. Davis, Adv. Drug Deliv. Rev. 2002, 54, 457; R. B. Greenwald, J. Controlled Release 2001, 74, 159; C. J. Damodaran, C. Fee, Eur. Pharm. Rev. 2010, 15, 18.

[11] K. W. Plaxco, D. R. Riddle, V. Gantcharova, D. Blake, Curr. Opin. Struct. Biol. 1998, 8, 80; Y. Zhang Y, Curr. Opin. Struct. Biol. 2008, 18, 342.

[12] W. F. DeGrado, Z. A. Wasserman, J. D. Lear, Science 1989, 243, 622; M. Mutter, Angew. Chem. Int. Ed. 1985, 24, 639; A. Pessi, Nature 1993, 362, 367; M. D. Struthers, R. P. Cheng, B. Imperiali, Science 1996, 271, 342; S. Olofsson, G. Johansson, L. Baltzer, J. Chem. Soc., Perkin. Trans. 1995, 2, 2047.

[13] M. Mutter, G. Tuchscherer, Makromol. Chem. Rapid Commun. 1988, 9, 437; M. Mutter, S. Vuilleumier, Angew. Chem. Int. Ed. 1989, 28 , 535; M. Mutter, G. Tuchscherer, Chimia 2000, 54, 552; M. Mutter, Trends Biochem. Sci. 1988, $13,261$.

[14] H. K. Rau, N. DeJonge, W. Haehnel, Proc. Natl. Acad. Sci, USA 1998, 95, 11526.

[15] M. Mutter, G. Tuchscherer, C. Miller, K.H. Altmann, R. I. Carey, D. F. Wyss, A. M. Labhardt, J. E. Rivier, J. Am. Chem. Soc. 1992, 114, 1463; G. Tuchscherer, C. Servis, G. Corradin, U. Blum, J. Rivier, M. Mutter, Protein Science 1992, 1, 1377.

[16] M. Mutter, P. Dumy, P. Garrouste, C. Lehmann, M. Mathieu, C. Peggion, S. Peluso, A.
Razaname, G. Tuchscherer, Angew. Chem Int. Ed. 1996, 35, 1482; U. Sila, M. Mutter, J. Mol. Recognition 1995, 8, 29; D. Banfi, B. Mandal, M. Mutter, L. Patiny, Acta Biochim. Pol. 2001, 48, 1105; S. Peluso, P. Dumy, I. A. Egglestone, P. Garrouste, M. Mutter, Tetrahedron 1997, 53, 7231.

[17] N. Srinivas, P. Jetter, B. J. Ueberbacher, M. Werneburg, K. Zerbe, J. Steinmann, B. vander Meijden, F. Bernardini, A. Lederer, R. L. A. Dias, P. E. Misson, H. Henze, J. Zumbrunn, F. O. Gombert, D. Obrecht, P. Hunziker, S. Shauer, U. Ziegler, A. Käch, L. Eberl, K. Riedel, S. J. DeMarco , J. A. Robinson. Science 2010, 327, 1010; M. Kümin, L.-S. Sonntag, H. Wennemers, J. Am. Chem. Soc. 2007,129, 466; H. Wennemers, M. Nold, M. Conza, K. J. Kulicke, M. Neuburger, Chem. Eur. J. 2003, 9, 442; G. Upert, F. Bouillère, H. Wennemers, Angew. Chem. Int. Ed. 2012, 51, 4231.

[18] C. Heinis, T. Rutherford, S. Freund, G. Winter, Nature Chem. Biol. 2009, 5, 502.

[19] V. Baeriswyl, C. Heinis, ChemMedChem 2013, 8, 377 .

[20] P. J. Flory, 'Statistical Mechanics of Chain Molecules', Hanser Publ., New York, 1988.

[21] C. Toniolo, G. M. Bonora, M. Mutter, Makromol. Chem. 1981, 182, 1997.

[22] T. Haack, M. Mutter, Tetrahedron Lett. 1992, 33, 1589.

[23] T. Wöhr, F. Wahl, A. Nefzi, B. Rohwedder, T. Sato, X. Sun, M. Mutter, J. Am. Chem. Soc. 1996, 118, 9218; P. Dumy, M. Keller, D. E. Ryan, B. Rohwedder, T. Wöhr, M., Mutter, J. Am. Chem. Soc. 1997, 119, 918; M. Keller, C. Sager, P. Dumy, M. Schutkowski, G. S. Fischer, M. Mutter, J. Am. Chem. Soc. 1998, 120, 2714.

[24] P. White, J.W. Keyte, K. Bailey, G. Bloomberg, J. Pept. Sci. 2004, 10, 18; T. Meier, $2^{\text {nd }}$ Bachem Spring Symposium, Basel, 2012; W. R. Sampson, H. Patsiouras, N. J. Ede, J. Pept. Sci. 1999, 5, 403; A. Abedini, D. P. Raleigh, Org. Lett. 2005, 7, 693; M. Keller, A. D. Keller, Bioorg. Med. Chem. Lett. 2001, 11, 857; N. Schmiedeberg, H. Kessler, Org. Lett. 2002, 4, 59; R. von Eggelkraut-Gottanka, Z. Machova, E. Grouzmann, A. G. Beck-Sickinger, ChemBioChem 2003, 4, 425.

[25] M. Keller, C. Boissard, L. Patiny, NN. Chung, C. Lemieux, M. Mutter, P. W. Schiller, J. Med. Chem. 2001, 44, 3896; M. Keller, T. Wöhr, P. Dumy, L. Patiny, M. Mutter, Chem. Eur. J. 2000, 6, 4358; F. Hubler, T. Rückle, L. Patiny, T. Muamba, G.-F. Guichou, M. Mutter, R. Wenger, Tetrahedron Lett. 2000, 41, 7193; A. Wittelsberger, M. Keller, L. Scarpellino, L. Patiny, H. Acha-Orbea, M. Mutter, Angew. Chem. Int. Ed. 2000, 39, 1111.

[26] 'Self-Assembling Peptide Systems in Biology, Medicine and Engineering', Eds. A. Aggeli, N. Boden, S. Zang, Kluver, Dortrecht, 2001.

[27] M. Stefani, C. M. Dobson, J. Mol. Med. 2003, 81, 678; P. T. Lansbury, H. A. Lashuel, Nature 2006, 443, 774; J. Hardy, D. J. Soelke, Science 2002, 297, 353; P. Hammerstroem, R. L. Wieseman, E. T. Powers, J. W. Kelly, Science 2003, 299, 713; C. Adessi, M.-J. Fossard, C. Boissard, S. Frage, S. Bieler, T. Rückle, F. Vilbois, S. M. Robinson, M. Mutter, W. A. Banks, C. Soto, J. Biol. Chem. 2003, 278, 13905.

[28] C. Soto, Nat. Rev. Neurosci. 2003, 4, 49; J.P. Taylor, J. Hardy, K.H. Fischbeck, Science 2002, 296, 1991.

[29] M. Mutter, R. Hersperger, Angew. Chem. Int Ed. 1990, 29, 185; M. Mutter, R. Gassmann, U. Buttkus, K.-H. Altmann, Angew. Chem. Int. Ed. 1991, 30, 1514

[30] M.Mutter, A. Chandraverkar, C. Boyat, J. Lopez, S. Dos Santos, B. Mandal, R. Mimna, K. Murat, L. Patiny, L. Saucède, G. Tuchscherer, Angew. Chem. Int. Ed. 2004, 43, 4172; S. Dos Santos, 
A. Chandravarkar, B. Mandal, R. Mimna, K. Murat, L. Saucède, P. Tella, G. Tuchscherer, M. Mutter, J. Am. Chem. Soc. 2005, 127, 11888.

[31] D. M. Coltart, Tetrahedron 2000, 56, 3449.

[32] Y. Soma, M. Sasaki, Y. Hayashi, T. Kimura, Y. Kiso, Chem. Commun. 2004, 124, 5965; Y. Hamada, H. Matsumoto, S. Yamaguchi, T. Kimura, Y. Hayashi, Y. Kiso, Bioorg. Med. Chem. 2002, 10, 4155; L. A. Carpino, E., Krause, C. D. Sferdean, M. Schürmann, H Fabian, M. Bienert, M. Beyermann, Tetrahedron Lett. 2004, 45, 7519 .

[33] I. Coin, R. Dölling, E. Krause, M. Bienert, M. Beyermann, C. D. Sferdean, L.A. Carpino, J. Org. Chem. 2006, 71, 6171.

[34] R. Mimna, M.-S. Camus, A.W.Schmid, G. Tuchscherer, H.A. Lashuel, M. Mutter, Angew. Chem. Int. Ed. 2007, 46, 2681; M.-S. Camus, S. Dos Santos, A. Chandravarkar, B. Mandal, A. W. Schmid, G. Tuchscherer, M. Mutter, H. A. Lashuel, ChemBioChem 2008, 9, 2104; G. Tuchscherer, A. Chandravarkar, M.-S. Camus, J. Bérard, K. Murat, A. Schmid, R. Mimna, H A. Lashuel, M. Mutter, Peptide Sci. 2007, 88, 239

[35] J. Chatterjee, T. Rechenmacher, H. Kessler, Angew. Chem. Int. Ed. 2013, 52, 254.

[36] N. Kamaly, Z. Xiao, P. M. Valencia, A. F Radovic-Moreno, O. C. Farokhzad, Chem. Soc. Rev. 2012, 41, 2971.

[37] R. B. Merrifield, 'Life during a Golden Age of Peptide Chemistry', Amer. Chem. Soc. 1993.

[38] K. Bund, M. Rohwetter, 'Wahnsinns-Typen: Wie gestört muss man sein, um Besonderes zu leisten? Erstaunlich viele Chefs sind psychisch auffällig', DIE ZEIT 2013, Nr. 34. 